$12-31-2020$

\title{
Empowering Botswana's rural communities through the Sustainable Livelihood approach: Opportunities and constraints
}

\author{
Keneilwe Molosi-France \\ University of Botswana, Gaborone, Botswana, molosik@mopipi.ub.bw \\ Kenneth Dipholo \\ University of Botswana, Gaborone, Botswana, dipholok@mopipi.ub.bw
}

Follow this and additional works at: https://scholarhub.ui.ac.id/ajce

Part of the Social and Behavioral Sciences Commons

\section{Recommended Citation \\ Molosi-France, Keneilwe and Dipholo, Kenneth (2020). Empowering Botswana's rural communities through the Sustainable Livelihood approach: Opportunities and constraints. ASEAN Journal of Community Engagement, 4(2), 342-359.}

Available at: https://doi.org/10.7454/ajce.v4i2.1101

Creative Commons License

(c) (i) ()

This work is licensed under a Creative Commons Attribution-Share Alike 4.0 License.

This Research Article is brought to you for free and open access by the Universitas Indonesia at ASEAN Journal of Community Engagement. It has been accepted for inclusion in ASEAN Journal of Community Engagement. 


\title{
Empowering Botswana's rural communities through the Sustainable
}

\section{Livelihood approach: Opportunities and constraints}

\author{
Keneilwe Molosi-France ${ }^{a^{*}}$, Kenneth Dipholo ${ }^{a}$ \\ aUniversity of Botswana, Gaborone, Botswana
}

Received: September $2^{\text {nd }}, 2020$ || Revised: November $18^{\text {th }} \&$ December $12^{\text {th }}, 2020||$ Accepted: December $26^{\text {th }}, 2020$

\begin{abstract}
Governments and other development stakeholders in many countries are increasingly investing in citizen and community empowerment as a key element in improving sustainable development outcomes. This focus hinges on the belief that putting communities at the fore front of their development and livelihood creation is an effective way to push communities to develop innovative ways of solving their own community problems and creating sustainable livelihoods. Botswana adopted this approach to development and the sustainable livelihoods approach (SLA) was engaged as one of the strategies for community empowerment and poverty alleviation. However, the SLA has not delivered the intended results so far. Thus, this paper argues that the SLA still has the capability to empower rural communities in Botswana to fight against poverty if appropriately used. The SLA focuses on people-centered sustainable development initiatives, which acknowledge that communities have strengths that need to be recognized and reinforced. This approach accepts that a livelihood is not only about economics, but involves capabilities, assets, and activities required for a means of living to cope with stress, recover, and provide sustainable livelihood opportunities for present and future generations. Based on this understanding, this paper sets out to contend that the SLA, despite its weaknesses, can still contribute effectively to the development agenda in Botswana's rural areas. This paper is informed by a desk review of the literature and relevant documents, and personal experiences of community development/extension workers. Therefore, using the SLA as a theoretical framework, the main purpose of this paper is to explore opportunities and constraints of the Sustainable Livelihoods Approach in the empowerment of the rural communities of Botswana.
\end{abstract}

Keywords: sustainable livelihoods approach; rural community; empowerment; poverty; people-centered development.

\section{Introduction}

Rural communities are faced with several social challenges, such as poverty and illiteracy, among others. Making a connection between poverty and illiteracy in rural areas, Lekobane and Mooketsane (2016) observed that rural areas are the most affected by poverty, because the job market does not favor rural workers, possibly due to low levels of education and literacy. Given this situation, many governments, including the Government of Botswana, attempt to improve the hopeless situations in rural areas as much as possible by introducing various development initiatives. However, these initiatives have proven to be problematic in their conception and implementation, which has failed to result in much improvement to the situation.

\footnotetext{
*Corresponding Author: molosik@mopipi.ub.bw
} 
Keneilwe Molosi-France, Kenneth Dipholo | ASEAN Journal of Community Engagement | Volume 4, Number 2, 2020

Most of the initiatives focus largely on the deficiency aspect of rural communities and overlook the capacities community members might have. According to Abiche (2012) the deficiency approach is usually focused on a mechanistic approach to local needs, instead of focusing on the existing capacities of community members that can contribute toward community building. The problem with this view is that it deals with people as potential clients and consumers, rather than empowered people who can drive their livelihoods by making decisions. The 'clientilist' perspective has rendered many rural communities in Botswana powerless and helpless and, thus, unable to exercise their capabilities in creating sustainable livelihoods for themselves. Due to this, rural communities in Botswana, and in most developing nations, find themselves faced with community development that focuses more on top-down bureaucratic development methods, where communities do not have a voice, but are merely objects of development for the most part.

This kind of development has been blamed for the persistence of poverty in many rural areas, despite efforts to alleviate it. This paper argues that the Sustainable Livelihoods Approach (SLA) can be used to empower rural communities, so that they are able to drive their own development, particularly in terms of fighting poverty and creating sustainable livelihoods. Using the SLA as a theoretical framework, the main purpose of this paper is to explore opportunities and constraints of the Sustainable Livelihoods Approach in the empowerment of rural communities in Botswana.

\subsection{Rural development context in Botswana}

When Botswana gained independence in 1966, rural and community development was one of the major priorities of the Botswana Government. As explained by Moepeng (2013), until the 1980 s more than $80 \%$ of the Botswana population lived in rural areas and the government needed to improve life in rural areas. The rapid economic growth after independence experienced mainly in rural communities did not benefit the masses. As noted by Gboku, Dipholo and Molosi (2009) this resulted in "a growth with uneven development."

Lekobane and Mooketsane (2016) indicated that rural areas in Botswana had the highest rate of impoverished individuals with rural areas accounting for 54\% of the total poor. According to Osei-Hwedie (2004), many contributing factors, such as a decrease in agricultural production and limited job opportunities in rural areas, have exacerbated this situation.

Furthermore, Mosha (2016) has blamed government "safety nets" in the form of subsidies and handouts for the poverty situation in rural Botswana. These safety nets contribute to a 
Keneilwe Molosi-France, Kenneth Dipholo | ASEAN Journal of Community Engagement | Volume 4, Number 2, 2020

'handout' mindset, according to Mosha, where people are not expected to do anything for themselves. This attitude was opposed for a long time by the country's first president, Sir Seretse Khama, who often stressed the importance of self-reliance. According to the president, improving living conditions is based on individual actions rather than the charity of others (Seekings, 2017). According to Seekings (2017), highlighted rural development programs aimed at improving the quality of life in rural areas through efforts that emphasize self-reliance rather than perpetual handouts.

Huge efforts have been expended toward rural development. However, these efforts were generally more anchored on a top-down development approach, whereby professionals and other outsiders had more say than the local people. This top-down approach to rural development planning and management largely stemmed from a need to accelerate the provision of basic services in the rural areas, through the Accelerated Rural Development Program (ARDP). The ARDP ensured that in a short space of time infrastructure such as classrooms and health posts and the like were available most rural areas of the country. Even though this were availed as important basic facilities, there was no real public involvement and communities were just passive recipients. Essentially, the top-down approach to rural development disempowered rural communities perhaps assuming that planners, by virtue of their decent education, were familiar with the needs of local people hence there was no need to involve the local communities in their own development. Specifically, rural communities had their development packages prescribed by bureaucrats. To a larger extent, the exclusion of local people from determining their own development under the pretext of accelerating improvements in the quality of life of the rural population has tended to lead to inappropriate, wasteful, and unsustainable development (Dipholo, 2002). This also eroded the erstwhile spirit of self-reliance and created an undesirable dependence on the state. Overall, this approach was mostly inefficient.

Although the government preached about people-centered development, it was mainly rhetorical with a problem-based view on poverty. This approach was mostly inefficient. Thus, an approach giving the local voice centre stage was necessary. From this perspective, there was a need to emphasize the engagement, empowerment, and participatory learning methods of the people. As such, bottom-up approaches to growth are favoured and assumed to produce more benefits as local citizens decide on interventions and goals for themselves. However, these methods appear to concentrate more on the problems faced in rural areas rather than on the 
Keneilwe Molosi-France, Kenneth Dipholo | ASEAN Journal of Community Engagement | Volume 4, Number 2, 2020

strengths that exist among rural residents and how they can be used to tackle poverty effectively.

Among several official efforts designed to improve rural livelihood, there is the 2002 Revised National Policy for Rural Development (RNPRD), the 1997 Community Based Strategy for Rural Development, and the Remote Area Development Program (RADP) of 1978. The mandate of the RNPRD policy is to improve participation in development planning and implementation processes by all concerned parties. The policy recognizes the need to involve other stakeholders, who could increase the competitive advantage of rural areas (Government of Botswana, 2002). The emphasis to involve other stakeholders deciphers the top-down approach to development planning as a purview of development experts.

In particular, the participatory development theory underscores that involving the community is one of the greatest ingredients in determining success in rural development (Dipholo and Molosi, 2017). This view of rural development is further expanded clearly within the Government of Botswana's Community Based Strategy for Rural Development (CBS). The CBS underlines the importance of community participation in identifying community needs and solutions. It emphasizes that activities meant to improve community livelihood should be initiated by the community through community structures (Mazibuko, 2017). In the context of the Community Based Strategy for Rural Development, communities would become primarily responsible for rural development activities, while government plays the role of facilitator. This strategy envisages devolution of development responsibilities and control to communities.

In spite of the hype and euphoria that accompanied CBS, interest on participatory rural development is still limited, especially within the government bureaucracy. This lack of interest is attributed to among others: government's passion for centralized strategic planning and the desire for rapid economic growth; existing centralized structures and procedures for planning and management of development; a long history of paternalism and superiority complex; government's cautious approach to decentralization and a noticeable lack of political will to support community participation; an entrenched dependency syndrome that is a result of untargeted social assistance schemes; persisting droughts, high levels of poverty and low levels of literacy (Dipholo, 2002). It is therefore clear that the shift from the top-down, centralized model of development planning to people-centred rural development lacks real political will and shall always be difficult given that the top-down, centralized strategic planning has served the country well, especially during its formative years. 
Keneilwe Molosi-France, Kenneth Dipholo | ASEAN Journal of Community Engagement | Volume 4, Number 2, 2020

While the RADP can be considered one of the government's efforts meant to contribute toward rural development, its focus is mostly on accelerating economic development in social services and infrastructure, while promoting economic and community development in remote areas (Seleka et al., 2007). The objectives of the program are mainly concerning the provision of basic services like education, health, and water, the promotion of income generation, and fostering self-reliance among communities residing in rural areas who are usually mostly people of San origin. The san are the indigenous people found in Botswana and other Southern African countries such as South Africa, Namibia, and Zimbabwe

The RADP development perspective has been critiqued by some scholars. One of the issues raised is that the program does not give prominence to community participation. As explained by Saugestad (2001) "the design of the Remote Area Development Program may be wellintended, but it is nevertheless top-down; initiated from a ministry, delegated to the district councils, and dispensed to communities." Molosi-France (2019) also addressed this question, claiming that the San policy programs are primarily based on development options from the top rather than the bottom and often ignore the real interests and needs of grassroots communities.

Some scholars relate this form of development to colonialism, where the dominant group imposes upon others their life ideology. For example, Ife (2010) contended that "the imposition of a developmental agenda on a community is characteristic of the colonialist project, where the coloniser is seen as having superior knowledge, wisdom and expertise and as therefore being able to impose their agenda on others." With regards to this, Chambers (1993) reminds us that the livelihoods of the rural poor are better understood by the poor themselves and outsiders can only learn in those situations and provide whatever assistance they can but can never be true masters of these situations.

Generally, there is a disturbing lack of and support for stimulation of economic activities and rural livelihoods, essentially because too much emphasis is placed on the provision of infrastructure projects that are politically convenient because they are easy to implement and can easily be seen or noticed as real visible development. It is on the basis of the recognition of the weaknesses of the top-down approach to the development of the rural communities that a paradigm shift anchored on empowered rural people has become a necessity. 
Keneilwe Molosi-France, Kenneth Dipholo | ASEAN Journal of Community Engagement | Volume 4, Number 2, 2020

\subsection{Empowerment: An enabler to 'thinking outside the box'}

As indicated by Ledwith (2011), a community is a context for both liberation and domination and there is a fine line between the two. Based on this context, the community can be the ground of both privilege and disempowerment, which may result in rural communities that maintain the status quo of inequality. As such, the empowerment of rural communities should be a critical concept to create more just and transformative communities, which are able to create their own livelihoods and alleviate poverty. As observed by Abiche (2012) empowerment should aim to enhance the possibilities for communities to control their own lives. This draws on the fact that communities understand their own problems and needs better than anyone else and, as such, should be given a conducive platform to define and act on them. Freire (1972) stresses that empowerment is a process which cannot be done for people, but which instead must be driven by the people themselves.

According to post-Marxist theory, empowerment is a strategy that can be used to fight disempowering activities through the collective mobilizations of marginalized groups (Ledwith, 2011). It should be noted that central to the concept of empowerment is the importance of individuals and communities having influence and control over decisions that affect them. According to Kinyashi (2006) empowerment is a process whereby communities are equipped with the knowledge, skills, and resources necessary for improving the quality of their lives.

Empowerment rests on the assumption that communities can engage in intelligent and shared decision making if the proper environment is availed. This implies that, if communities are not empowered and are asked to make decisions, they may not be competent enough to defend their interests (Kinyashi, 2006). According to Cornwall (2002), expecting the poor to participate in decision making without empowering them undermines the very possibility of equitable consensual decision making, thinking outside the box, and maintaining hegemonic perspectives, which results in status quo solutions. This challenge the obvious assumption in the participation rhetoric that people can participate provided they are brought into the decision-making platforms. This situation has disadvantaged rural communities by entering unequal relations where they still do not have a voice.

As explained by Freire (1972), the concept of empowerment is focused on ensuring that rural communities can understand their lives for what they are and gather the ability to gain power to be in control as human beings who are able to think and reflect. In relation to empowerment, Freire (1972) emphasizes that the rural poor should be encouraged to reflect 
Keneilwe Molosi-France, Kenneth Dipholo | ASEAN Journal of Community Engagement | Volume 4, Number 2, 2020

on their position in society and gauge how their own strengths and resources can be utilized to move them out of their oppressed status. Freire's (1972) views are founded on the aspect of conscience, which is the process of becoming critically aware of the structural forces of power that shape our lives and action for change (Ledwith, 2011).

Critical consciousness allows people to recognize disempowering actions and act to gain their freedom. As Budiriwanto (2007) argues, empowerment begins with how people see themselves. If people are unable to critically analyse their situations and, instead, internalize the values of the oppressors and see themselves as unable to change the status quo, there is little they can do, even if they are brought into the decision-making platforms. As Ledwith (2011) indicates, perceptions of powerlessness erode hope and create a culture of silence, while van der Merwe, Mberengwa and Lekoko (2009) emphasizes that the social structure consistently tells the "powerless" that they can do little for themselves. This is what Freire (1972) labels internalized powerlessness/oppression, whereby the community has an internalized belief that change cannot occur, thus, the community is unwilling to struggle for more control and influence. Based on the ideas discussed above, this paper contends that the sustainable livelihoods approach (SLA) can be useful in transforming the livelihoods of rural communities as the approach recognizes that rural communities, although poor, have strengths that can be explored instead of focusing on weaknesses and problems.

\subsection{The sustainable livelihood approach (SLA)}

The SLA has a people-centered focus to community development, which emphasizes the participation and responsiveness of end users (Abiche, 2012). From the empowerment perspective, the basic argument of the SLA is that powerful communities are built through the capacity of their members. This is based on the idea that the rural poor often understand their situation and needs best and must be actively involved in the interventions meant to better their situation. In this regard, poor people must be key in identifying and addressing livelihood priorities, while outsiders need to listen and respond to the rural poor (Kadozo, 2009). As such, the SLA aims to place people, and the households in which they live, at the centre of the development process, starting with their capabilities and assets rather than their problems. This is a shift of focus from needs-based solutions to a focus on people and their capacity to initiate and sustain positive change (Altarelli \& Carloni, 2000). This suggests that the approach does not enforce a client list perspective in its effort to better people's lives; rather, it acknowledges that the rural poor are people who can make rational decisions and choices 
Keneilwe Molosi-France, Kenneth Dipholo | ASEAN Journal of Community Engagement | Volume 4, Number 2, 2020

about their lives. This is also underscored by Paulo Freire's critical pedagogy, which argues that the development process is only liberative to communities when the impetus for social change comes from the grassroots, from the communities themselves, as they understand their conditions better. As May, Mair and Finch (2009) explain, "a critical aspect of the SLA is that it allows people-both individually and collectively-to analyse and develop new insights into their own situations, to understand better that they themselves have skills and assets and to develop strategies to move forward."

According to Chambers and Conway (1992) a livelihood is made up of capabilities, assets, and other activities required for a means of living. Capabilities involve people's ability to cater to their basic needs, as well as the opportunities for personal and social development. Basically, capabilities are anchored on the opportunities and options individuals must effectively address their personal concerns, and the creation of a sustainable livelihood. Anaafo (2014) explains that capabilities can take the form of laws, communication systems, policies, conflict resolution mechanisms, resource allocation strategies, planning frameworks, and participatory approaches that are seen by the poor as enabling and just enough to support their ability to access, use, and manage resources.

According to Sen (1992), capabilities are influenced by several factors such as personal, social, and environmental conversion factors. The personal conversion factors are those personal characteristics that determine one's ability to create a sustainable livelihood, such as intelligence, gender, and skill. The assumption is that one's intelligence or skill can influence their creativity toward the creation of a livelihood. The social conversion factors refer to how the socio-economic platform inhibits/allows for one to create a livelihood. This point emphasizes such things as policies and programs, social norms and power structures, and relations. On the other hand, environmental conversion factors refer to the environmental conditions that inhibit the creation of livelihood, such as climate and geographical location.

According to Chambers and Conway (1992), assets refer to resources and stores (tangible assets) and claims and access (intangible assets), which a person or household commands and can use toward a livelihood. Assets refers to both material and immaterial resources that a household or community possesses. Mazibuko (2013) explained that every community has resources, even the poorest or most marginalized. Assets can be understood as five forms of capital-human, social, physical, natural, and financial. Human capital consists of education, skills, knowledge, health, values, leadership capacity, interpersonal skills, and labour (Mazibuko, 2013). The assumption is that human capital has implications for livelihood 
Keneilwe Molosi-France, Kenneth Dipholo | ASEAN Journal of Community Engagement | Volume 4, Number 2, 2020

creation. For instance, one's ill health may mean that the person's capability and access to a sustainable livelihood is negatively affected. Education and skills are also important as human assets, because skills can be used to create a livelihood. For example, someone with carpentry or basket weaving skills can create a livelihood by making crafts.

On the other hand, social capital speaks to trust, mutual understanding, and shared values and behaviours that bind community members together and make cooperative action possible (Cohen \& Prusak, 2002). Within this context, networks are created to provide a way of escaping economic shocks, such as funeral costs, because friends, family, and/or club members will always be on hand to help (Mazibuko, 2013). Physical capital refers to the tools and equipment people need to be productive, along with the basic infrastructure needed to function, such as affordable transport, decent housing, and access to information (May, Mair, \& Finch, 2009). Finally, financial capital includes earned income, savings, and access to credit facilities. Income is very important in the creation of livelihood because it can give a household access to the necessities of life. For example, having money makes a household capable of buying enough food and accessing quality medical care and education. However, it should be noted that while the SLA acknowledges income/money as important in creating livelihood, it is not considered to be the sole determinant of poverty.

\section{Methods}

This paper adopts a qualitative approach to data collection from secondary data sources and personal experiences of community development/extension workers. A desk review of relevant government documents on SLA and literature was undertaken to explore opportunities and constraints of the Sustainable Livelihood Approach in the context of rural communities of Botswana. In particular, the Strategic Framework for Community Development in Botswana, the Botswana Operational Guidelines for Implementing the Sustainable Livelihoods Approach, and the Community Action Plans were reviewed. These documents serve as references for community development workers who are involved in the planning and implementation of the SLA in Botswana.

Data was also collected from two community development/extension workers who are directly involved in the implementation of the SLA. The two-community development/ extension workers were purposively selected, because the researcher was aware that they were working on the SLA and, therefore, had the required information. As Taherdoost (2016) 
Keneilwe Molosi-France, Kenneth Dipholo | ASEAN Journal of Community Engagement | Volume 4, Number 2, 2020 explained about purposive sampling, it is where the researcher handpicks the cases to be included in the sample based on their judgment of their typicality.

\section{Results and Discussion}

\subsection{Opportunities of SLA in the context of rural development in Botswana}

In Botswana, the SLA was piloted in Ghanzi District Council, Chobe District Council, and Selebi Phikwe Town council in 2011 (Ministry of Local Government, 2010). However, the approach did not survive past the pilot stage, as it was never rolled out to the other districts across the country. Almost a decade after piloting SLA, the implementation and roll out of the approach has yet to commence. The SLA, like previous similar initiatives, such as the Participatory Rural Appraisal, Community Based Strategy for Rural Development, seems to have failed before take-off. It appears that the government's efforts toward effective implementation of the approach were wasted, as attention was given to new and upcoming community development models, such as the Local Economic Development. Although the approach seems to have been abandoned, this paper argues that the SLA, despite its weaknesses, can still contribute effectively to the rural development agenda and help in the alleviation of poverty.

As explained by van der Merwe, Mberengwa and Lekoko (2009), most of the poverty alleviation efforts in Botswana focus on addressing the immediate needs of the poor to relieve them of poverty symptoms mainly through the provision of social safety nets, which have the unintended effects of creating further dependency on the government. These efforts fall short of empowering the poor to eventually take control of their lives. As explained by Mosha (2015), safety nets do not address the root cause of poverty, but instead create dependency. This speaks to several poverty alleviation efforts that the Government of Botswana is focusing on, such as monthly food packages under the Destitute Program and the poverty eradication program, which have to a large extent entangled people into the poverty trap as they are mainly focused on service provision rather than empowerment. This understanding of poverty is problematic. Instead of empowering the poor so that they can graduate out of poverty through their already existing strengths, it starts from trying to address the symptoms of poverty. Within the understanding of SLA, the strengths within a community provide a positive opportunity to move away from a client list mentality, whereby they are considered incapable of selfdevelopment. This view on poverty alleviation results in a dependency syndrome, which many consider to be further disempowerment. As Ireni-Saban (2019) argued, dependence is 
Keneilwe Molosi-France, Kenneth Dipholo | ASEAN Journal of Community Engagement | Volume 4, Number 2, 2020

decadent. Its by-products are laziness, degeneration, and poverty. It is a way of life transmitted to the young, which generates cycles of dependency.

Considering this, all players in rural development-the poor, the government, and community development workers-should change their mindset. This is critical, because poverty alleviation has mainly been focused on the government provision of social services, which becomes mostly rhetoric about community participation and bottom-up community planning and decision making. Empowered communities can initiate livelihoods for themselves and step away from relying on the state for their livelihoods, as stated by Tannahall (2014). Dependence and self-reliance are particularly important for the rural poor because the social structure has pushed them into a state of learned self-helplessness, where they have lost belief in their own abilities and believe that they can only be helped by outsiders. As Budiriwanto (2007) explained, empowerment is a process that begins from within, with people seeing themselves as capable and worthy.

According to Freire (1972), the poor, the oppressed, and the marginalized can and should be encouraged to analyze their position in society and assess how their own strengths and resources can be utilized to lift them out of poverty. Based on the SLA, the government and other stakeholders are required to develop and express a new level of trust in the ability of communities to create positive outcomes for themselves (Tannahal, 2014). However, usually the problem is that there is too much rhetoric when it comes to exchanging power positions with the poor. Their decisions are not well trusted, and the government continues to withhold some power. It appears that even when there is a call for bottom-up planning in development in Botswana, it is merely rhetoric and the government has yet to come to terms with giving power to communities, let alone to community development workers who serve on the ground in communities. This becomes a problem for the SLA to be implemented with its emphasis on bottom-up planning by communities.

It is important to note that unlike other approaches, the SLA recognizes that poverty is multidimensional and experienced differently. As such, the poor engage in different activities to create a livelihood. In this case, community profiling is critical for poverty alleviation interventions. The SLA emphasizes that people have assets and capabilities that they combine to create a livelihood for themselves. This is crucial, particularly in the case of poor communities that must rely on several activities for their survival. For example, most rural households in Botswana rely on different survival activities, depending on the season, such as piece jobs, 
Keneilwe Molosi-France, Kenneth Dipholo | ASEAN Journal of Community Engagement | Volume 4, Number 2, 2020

dressmaking, mafisa, metshelo, and selling crafts, phane, wild fruits, etc. SLA acknowledges that all these different activities are important and have been helping households get by daily.

As such, it is critical to empower the community to create ways to strengthen these activities, so that they are more effective in contributing to livelihood creation. As livelihoods depend on capabilities, communities can be given basic bookkeeping skills, so that they improve the way they do their metshelo and perhaps open a cooperative that can increase their returns. In this example, the SLA moves away from external development efforts that neglect and downplay local knowledge and values (Steiner \& Farmer, 2018). Instead of the Government of Botswana and other stakeholders taking the lead in directing poverty alleviation activities, they would only take the role of facilitator. What is important is to direct focus to ensure that structures of support are available to strengthen poor people's assets and capabilities. As noted by van der Merwe, Mberengwa and Lekoko (2009), the government's major role should be in providing the necessary informal and formal support structures and regulatory frameworks for these different ways of livelihood to be translated into sustainable ways of livelihoods.

As Sen (1992) indicated, the capability to translate assets into sustainable ways of livelihood depends on different conversion factors, such as the policy environment. Therefore, it is critical to understand how policy making is shaping, and is shaped by, indigenous knowledge and other ways of life in the context of rural Botswana. Do policies and the legislature allow rural communities to turn their assets and capabilities into livelihoods? In the context of rural communities, this can be applied to different areas, such as the recognition of traditional medicine to create a livelihood. Traditional medicine plays a very critical role in livelihood creation in Botswana, because it contributes to human capital in terms of good health and financial capital for those who earn an income by providing traditional medical care. In this regard, policies and legislature should be providing a good environment for co-existence and co-production of knowledge.

For instance, instead of dismissing traditional medicine, the Government of Botswana can rather work toward co-production of knowledge, whereby scientific and traditional knowledge can learn from each other. It is notable in this regard that the SLA understands livelihood strategies and outcomes as not solely dependent on access to capital assets or constrained by the vulnerability context; they are also transformed by the environment of structures and processes (Serrat, 2017). This implies that poverty is not only about a lack of, but also access to, resources due to unfavorable legislation and policy. SLA requires reflection into the policy and legislation structures and processes to ensure that these structures do not obstruct the poor 
Keneilwe Molosi-France, Kenneth Dipholo | ASEAN Journal of Community Engagement | Volume 4, Number 2, 2020

from creating livelihoods. Based on this view, from the SLA perspective, policy makers are required to design intervention strategies that will encourage equitable access to resources even for the average citizen. The SLA gives a good opportunity for Botswana to fight poverty by ensuring that the legislature and policy decisions do not further press people into the trap of poverty and difficulty. The Government of Botswana has already made efforts in piloting this approach, but the weak link between the SLA and existing policies, procedures, and methods is a great concern and could be the reason why implementation has stalled.

\subsection{Constraints of SLA in the context of rural development in Botswana}

Despite the opportunities that can be derived from the SLA, there are challenges that need to be appreciated for a better use of the approach. SLA has been criticized for portraying a value free and power neutral analysis of poverty and livelihoods. Morse \& McNamara (2013) argued that failing to take power dynamics into consideration, as it relates to gender, for example, weakens the approach and ignores issues involved when negotiating sustainability and inclusion/exclusion from assets. This weakness in the approach can be strengthened by ensuring that gender mainstreaming is part and parcel of the SLA processes. This is evident even in the SLA community action plans for the piloted areas. Gender does not seem to be one of the critical issues to be considered in undertaking the SLA processes. As the contacted officers explained, they do not undertake a systematic gender analysis, but may only use equal numbers of men and women in a project. Unfortunately, this kind of equality will not bring equitable results, because both men and women have different experiences. In fact, as Mosse (2007) contended, social structures create status positions that define entitlements to resources and gender mainstreaming should be key in the SLA processes.

Ludi and Slater (2008) observed that another weakness of the SLA is its ahistorical understanding of livelihoods and poverty. Being ahistorical is problematic, because historic issues that shape people's livelihoods now and in the future are not addressed and, thus, the status quo is maintained. This could be a genuine concern when we talk about poverty among other excluded groups in Botswana, such as the San whose poverty has a historical perspective to it. As Molosi-France (2019) argued, the San are not only poor due to their lack of basic resources, but they are also poor because of the complex historical issues centering on their social interactions with the dominant Tswana speaking groups. Therefore, extra care is required in this regard. If history is ignored, the SLA may only result in some add-on solutions that are only beneficial in the short term. 
Keneilwe Molosi-France, Kenneth Dipholo | ASEAN Journal of Community Engagement | Volume 4, Number 2, 2020

On the other hand, it must be appreciated that, like other participatory approaches, the SLA is very challenging and demanding. It requires careful and flexible planning. This takes more time, which is a luxury, especially for the political leadership who would have made promises to voters and therefore desirous of seeing development taking place sooner than later in order that voters are appeased, and votes guaranteed at the next election. Community development officers are often pressed to show the results of their programs and, as a result, tend to focus more on programs whose results are likely to be instant and visible. Thus, the reality of government planning, often influenced by short-term political gains, as well as the requisite capacity for implementation of the SLA, could considerably reduce the effectiveness of its application, especially in developing countries like Botswana, which desires rapid development.

As has been evidenced by community development workers, if the SLA was to be implemented by the book, more time is needed, but sometimes communities are not given this time due to the potential negative effect on political gains. Thus, to fast-track progress for political recognition, politicians tend to sway the process away from the proper track and end up choosing projects and processes for the communities. This is problematic, because it uses the 'client list' problem-based approach and presents communities as unable to provide solutions to their own problems. Also, it has been argued that for political gains, the SLA was not given enough time before it was properly rolled out, so that other approaches could be implemented and receive attention instead.

Another challenge for SLA to be effective is that there is need for political will. Those in decision-making structures should strongly support the approach because that creates a desirable environment for the SLA to effectively function. For instance, issues of lack of funds to train community development officers and other trainers seem to be an issue of concern among community development workers. The belief is that, if decision makers are not committed to SLA, they will not avail enough resources to undertake the approach. On the other hand, if decision makers support the approach, it suggests that they will support bottom-up development planning instead of top-down planning and decision making.

\section{Conclusion}

As indicated in the paper, although the SLA has weaknesses and does not arrive at a perfect set of interventions, its ideas can be useful in the fight against poverty to some extent. Instead of the rural poor in Botswana choosing from a list of tailor-made projects, SLA encourages development and poverty interventions that recognize the poor as subjects, rather than the 
Keneilwe Molosi-France, Kenneth Dipholo | ASEAN Journal of Community Engagement | Volume 4, Number 2, 2020 object of interventions. This approach will result in poverty and development interventions that appreciate the different livelihood activities that rural communities engage in for their survival. From this perspective, this paper has argued that rural communities undertake different livelihood activities and experience poverty differently, which calls for the strengthening of community engagement by moving them from the peripheries into the core.

Despite its constraints, the SLA can still benefit the rural poor in the Botswana context. As argued in this paper, the Government of Botswana has not given the approach time for testing and has been slow to implement it, which resulted in it mostly losing its vigor at the piloting stage. As such, it is recommended that a proper and committed implementation of the SLA should be put on the table, guided by a detailed implementation plan and methodically prepared manual for the relevant personnel. When this is done, it is important to consider the relational power issues which may stifle the benefit of some already powerless groups in the process.

\section{Author Contribution}

Keneilwe Molosi-France conceived of the presented idea and developed the theory. Kenneth Dipholo verified the analytical methods with SLA Framework. All authors discussed the results and contributed to the final manuscript.

\section{References}

Abiche, T. T. (2012). Community empowerment and sustainable livelihoods: Transforming social capital into entrepreneurship in rural Southern Ethiopia [Postgraduate thesis, University of South Africa]. UNISA Institutional Repository.

\section{http://uir.unisa.ac.za/handle/10500/10190}

Altarelli, V., \& Carloni, A. (2000). Inter-Agency Experiences and Lessons: DFID/FAO Forum on Operationalising Sustainable Livelihoods Approaches. Rome: FAO.

Anaafo, D. (2014). Sen's Capability Approach: An Analytical Tool to Poverty Analysis in Land Reform Environments. Journal of Land and Rural Studies, 2(1), 1-19. https://doi.org/10.1177\%2F2321024913515267

Brown, B. (2005). The incorporation of poverty into adult identity overtime in Botswana: Transformation tales and implications for adult education. International Journal of Lifelong Education., 24(5), 393-404. https://doi.org/10.1080/02601370500169731 
Keneilwe Molosi-France, Kenneth Dipholo | ASEAN Journal of Community Engagement | Volume 4, Number 2, 2020

Budiriwanto, B. (2007). Pesantren and participatory development in Indonesia. Canberra: Australian National University. https://doi.org/10.25911/5d7a28313ff44

Chambers, R. \& Conway, G. R. (1992). Sustainable Rural Livelihoods: Practical Concepts for the 21st Century. UK: Institute of Development Studies.

https://opendocs.ids.ac.uk/opendocs/handle/20.500.12413/775

Chambers, R. (1993). Challenging the Professions: Frontiers for Rural Development. UK: Intermediate Technology Publications Ltd (ITP).

https://www.cabdirect.org/cabdirect/abstract/19941802488

Cohen, D. J. \& Prusak, L. (2002). In Good Company: How Social Capital Makes Organizations Work. Harvard Bussiness Review, 80, 107-113.

http://providersedge.com/docs/book_reviews/In_Good_Company.pdf

Cornwall, A. (2002). Making spaces, changing places: Situating participation in development. Working paper series, 170.IDS https://opendocs.ids.ac.uk/opendocs/bitstream/handle/20.500.12413/3932/Wp170.p df

Dipholo, K. B., \& Molosi-France, K. (2017). The mismatch between the theory and practice of participatory rural development in Botswana: prospects for transformative social change. International Conference on Public Administration and Development Alternatives (IPADA).

Dipholo, K. B. (2002). Trends in participatory Development. Journal of Social Development in Africa, 17(1), 59-79. https://doi.org/10.4314/jsda.v17i1.23846

Fisher, S. (2002). A Livelihood less Ordinary: Applying the Sustainable Livelihoods Approach in the Australian Indigenous Context. Alice Springs, NT: Centre for Appropriate Technology.

Freire, P. (1972). Pedagogy of the Oppressed. London, UK: Penguin Books. https://www.penguin.co.uk/books/225/22583/pedagogy-of-theoppressed/9780241301111.html

Gboku, M., Dipholo, K. B. \& Molosi, K. (2009). Training needs assessment of rural training centers and the application of indigenous knowledge. University of Botswana

Government of Botswana. (2002). Revised National Policy on Rural Development. Botswana: Ministry of Finance and Development Planning.

Ife, J. (2010). Capacity building and community development. In S. K. \& M. Clarke (Ed.), Challenging Capacity Building: Comparative Perspectives (pp. 67-84). London: Palgrave Macmillan. https://doi.org/10.1057/9780230298057_4 
Keneilwe Molosi-France, Kenneth Dipholo | ASEAN Journal of Community Engagement | Volume 4, Number 2, 2020

Ireni-Saban, L. (2019). Diplomacy in Times of Disaster: Management through Reputational Capital. Journal of Management Policy and Practice, 20(3).

https://doi.org/10.33423/jmpp.v20i3.2234

Kadozo, N. (2009). Sustainable Livelihood Approaches: The future for income generating projects in urban areas? An evaluation of five income generating projects in Tembisa [Doctoral dissertation, University of South Africa]. UNISA Institutional Repository. http://uir.unisa.ac.za/handle/10500/3248

Kinyashi, G. (2006). Towards Genuine Participation for the Poor. Tanzania: Spring. http://www.eldis.org/fulltext/genuine_participation.pdf

Ledwith, M. (2011). Community development: A critical approach. (2nd ed.). Bristol: Policy Press.

Lekobane, K.R and Mooketsane, K. (2016). Rural Poverty in Botswana: A Gendered Analysis. Journal of Social and Development Sciences, 7(1), 48-58.

https://doi.org/10.22610/jsds.v7i1.1235

Ludi, E., \& Slater, R. (2008). Briefing Note for the Poverty-Wellbeing Platform. Briefing note, Swiss Agency for Development and Cooperation. London: ODI.

Maphosa, F., Nta, U. C., \& Seleka, M. (2019). An Appraisal of Participation and Rural Development in Botswana: The Case of Mmankgodi Village. Botswana Notes, 51, 78-92.

Mazibuko, S. (2013). Understanding Underdevelopment through the Sustainable Livelihoods Approach. Community Development, 44(2), 173-187.

https://doi.org/10.1080/15575330.2012.683798

May, C. R., Mair, F., \& Finch, T. (2009). Development of a theory of implementation and integration: Normalisation process theory. Implementation Science, 4(29), 1-9.

\section{https://doi.org/10.1186/1748-5908-4-29}

Ministry of Local Government. (2010). Recommendations of the report of the task force on the review of the impact of the Remote Area Development Programme on the livelihoods of remote area dwellers. Gaborone: Applied Research Unit.

Moepeng, P. (2013). Rural development in Botswana: Experience from elsewhere and emerging issues (No. 1745-2016-141003).

Molosi-France, K. (2018). A Relational View of San Poverty in Botswana: A Case Study of Khwee and Sehunong. South African Review of Sociology, 49(3-4), 1-15. 
Keneilwe Molosi-France, Kenneth Dipholo | ASEAN Journal of Community Engagement | Volume 4, Number 2, 2020

Morse, S., \& McNamara, N. (2013). Sustainable livelihood approach: A critique of theory and practice. Berlin, Germany: Springer Science \& Business Media.

Mosha, A. (2015). Urban agriculture in Botswana. Commonwealth Journal of Local Governance, 18(4842), 48-67. https://doi.org/10.5130/cjlg.v0i18.4842

Mosse, D. (2007). Power and the durability of poverty: A critical exploration of the links between culture, marginality and chronic poverty. Manchester: Chronic Poverty Research Center.

Osei-Hwedie, K. (2004). Poverty eradication in Botswana: Towards the realisation of vision 2016. Pula: Botswana Journal of African Studies, 18(1), 7-18.

http://hdl.handle.net/10311/894

Robeyns, I. (2005). The Capability Approach: a theoretical survey. Journal of Human Development, 6(1), 93-117. https://doi.org/10.1080/146498805200034266

Saugestad, S. (2001). The inconvenient indigenous: Remote area dwellers in Botswana, donor assistance and the first people of the Kalahari. Sweden: Nordic Africa Institute.

Seekings, J. (2017). The discourse of dependency and the agrarian roots of welfare doctrines in Africa: The case of Botswana. Sozialpolitik, 2(2), 1-23. https://doc.rero.ch/record/306439

Seleka, T. B., Siphambe, B., Ntseane, D., Mbere, N., Kerapeletswe, C., Sharp, C. (2007). Social safety nets in Botswana: Administration, targeting and sustainability. Gaborone, Botswana: Lightbooks.

Sen, A. (1992). Inequality Reexamined. New York, USA: Oxford University Press.

Serrat 0. (2017.). The Sustainable Livelihoods Approach In Knowledge Solutions. Singapore: Springer. https://doi.org/10.1007/978-981-10-0983-9_5

Steiner, A. A., \& Farmer, J. (2018). Engage, participate, empower: Modelling power transfer in disadvantaged rural communities. Politics and Space, 36(1), 118-138.

https://doi.org/10.1177\%2F2399654417701730

Taherdoost, H. (2016). Sampling methods in research methodology; How to choose a sampling technique for research. International Journal of Academic Research in Management, 5(2), 18-27. https://dx.doi.org/10.2139/ssrn.3205035

Tannahall, C. (2014). Community empowerment and building. Edinburgh: The Royal Society of Edinburgh.

van der Merwe, M., Mberengwa, L. R., \& Lekoko, R. N. (2010). Community empowerment in Botswana: the practitioners perspective. Journal of Family Ecology and Consumer Sciences, 38, 13-22. 